\title{
Public Perception on Solid Waste Management and Related Government Policy
}

\author{
Article by Akbar Salihu \\ Master in Public Health, Texila American University, Nigeria \\ E-mail: gwamaduniya@yahoo.com
}

\begin{abstract}
Solid waste is the unwanted or useless materials generated from combined residual, industrial and commercial activities in a given area. Rapid population growth in urban communities and change in consumption pattern are responsible for increase in solid waste production. With the significant increase in urbanization and population, solid waste accumulation is in the for-front, and the improper disposal of such waste materials will lead to an unsanitary conditions, leading to environmental pollution and outbreak of diseases. The above research will be carried out to help the government establish a policy for proper solid waste management for better environment.
\end{abstract}

\section{Introduction}

Solid waste are materials discarded after being used for the purpose for which they served as resources. Solid waste can also mean the unwanted or useless materials generated from combined residual, industrial and commercial activities in a given area (Gupta M. S. 2016). Rapid population growth in urban communities and change in consumption pattern are responsible for increase in solid waste production (Ogeda-Benitez and Berand Lozano, 2003). Fast foods usually come in polythene bags and cans which add up to solid wastes, most urban settlers patronize the use of fast foods. Especially the cans, it serves as a water collection units giving rise to good habitation of vectors like mosquitos. Polythene bags takes decades without disintegration, giving a bad outlook of the environment and pollution. Solid waste management is a serious problem in Nigerian cities. It is estimated that an average Nigerian generates about $0.49 \mathrm{~kg}$ of solid wastes per day with households and commercial centers contributing almost $90 \%$ of the total urban waste burden (P. O. U. Adogu 2015). A government policy on sanitation is a deliberate system of principles to guide decisions and achieve rational outcomes on sanitation under the government. It can also mean a statement of intent, and is implemented as a procedure or protocol according to Wikipedia. Policies are generally adopted by the Board of or senior governance body within an organization.

\section{Area under the study}

(Wikipedi) Kurmi Market is a large market in the city of Kano, Kano State, Nigeria. Founded by Muhammad Rumfa, a King of Kano, in the 15th century, it is still in use in the 21st century. As of 2003, Sale Ayagi was chairman of the market's unions. Kurmi Market has lent its name to a football team. Kurmi market was established in the fifteenth century as a trading and warehousing center for the growing commercial activities in the city, a result of expanding regional and Trans-Saharan trade. It was built within the Jakara district of the city. At the time of its development, Kano had become a regional center of trade in agricultural produce with a functional industry in weaving, cloth dyeing, leather making and potter, this contributed to the attraction of the city to itinerant traders from Western Sudan, Tripoli and Ghadames who came to buy goods. Prior to the pre-colonial period, the market structure was organized in a quadrangle shape with bamboo stalls forming rows like an irregular street; within the market, particular quarters served distinct products and the cattle trade was located in the westernmost parts and outskirts of the market. The market was administered by individuals who supervise specific quarters or produce sections. In 1904, the old market was demolished and a new one built so as to improve revenue generation for the Kano Native Authority. The new market opened in 1909 and was composed of 755 stalls made of clay, it also had a mosque and a courthouse. Over the years incremental improvements took place, the streets were widened and some livestock sellers were asked to relocate. The surrounding of the market, in particular the Jakara area also witnessed expanded development. However, the direction of trade changed away from the city's northern neighbors and 
Trans-Saharan trade to trade with the Southern neighbors and Europeans. In 1969, the administration of the market fell into the hands of the Kano Local Government.

Kano metropolis/municipal with coordinates: $11^{0} 57^{\prime} 07^{\prime \prime} \mathrm{N} 8^{0} 32{ }^{\prime} 25^{\prime \prime} \mathrm{E}$, is a local government area within the Kano urban area in Kano state, also known as the capital of Kano state, Nigeria. Its headquarters is at Kofar kudu (western entrance of emir's palace), in the south of the city of Kano. It has an area of $17 \mathrm{~km}^{2}$ and population of 365,525 at the 2006 census. Like most cities in the developing world is messed up with several tons of solid waste materials left uncollected on the streets each day, making it a good habitat for paste to breed and cause disease, clogging of the sewage/drainage leading to flooding of environment especially during the rainy season. Substantial number of members in the metropolis have little or no access to at all to solid waste collection services. This is because greater percentage of the population are poor and are not willing to pay for the services if provided by private organizations.

\section{Reasons for growing waste}

Urbanization and industrialization contributes to the problem and is exacerbated by inadequate and inefficient final disposition of solid and liquid waste. There are a unit numerous reasons for growing municipal waste generation, which includes Changing Lifestyles, Food Habits, Change in Living Standards, Fast Economic Development and Urbanization (Gupta M. S. 2016).

\section{Types of solid waste}

Solid waste can be categorized according to their origin as;

- Domestic or Residential wastes which are waste derived from households composed of garbage, refuse, ashes and bulky materials like wood furniture, bedding, rubber tires or rugs or,

- Commercial wastes derived from wholesale and retail trade, hotels and offices. These wastes include garbage, refuse, ashes and bulky materials too.

- According to Danbuzu (2011), Ibrahim categorized solid waste into three types, based on their composition. These are:

- Biodegradable mainly composed of garbage trash;

- semi-biodegradable, this consists of rubbish;

- And non-biodegradable that comprises scraps and other carcasses.

- Aibor and Olorunda (2006) generalized solid wastes into

- Domestic solid wastes which are generated directly from households. These include garbage, rubbish, ashes, house sweepings, other domestic bulky wastes, etc. and,

- Estate solid wastes which are generated in larger quantities and are mostly from industrial establishments, hospital wastes, municipal wastes, agricultural wastes, site demolition and construction activities, etc.

\section{Integrated solid waste management}

Solid waste management includes collection from designated sites within the community into vans to tipping sites. Then separation into each type, processing such materials, solids maybe taken for land fill for disposal, toxic ones for incineration, treating and recycling then final disposal.

Danbuzu (2011) wrote on methods of refuse disposal techniques which are teamed up under four main groups namely: - Burial method, Burning method, Recycling method and Controlled tipping method.

1. Burial Method:- Under this method, refuse is literarily buried, unwanted materials like broken bottles, potsherds or sanitary landfill composting is also associated with burying. This method has impact seriously on the health of man himself. For instance, nobody would like to have refuseburial site within his vicinity because of the harmful effect they generate. After the burial of organic matter, there may be leachate that often pollutes the aquifers, wells and boreholes. Hole dug in that premises will definitely not produce portable water for human consumption. It is a common knowledge that organic matter generates heat when buried, thereby causing the production of methane known as biogas. If methane could penetrate further away from the source, it is capable of killing vegetation, which may hamper agricultural activities which also have far reaching effects on man. 
2. Burning (Incineration) Method: - it has been argued that an average Nigerian produces about 0.45 gram per day to refuse, the composition and quality of the refuse vanes depending on factors guiding refuse disposal as mentioned earlier. The major component is organic matter, which account for $60-80 \%$ of the total waste. Incineration is a common method of disposing refuse; it has its short comings because it is not an end point itself, but nearly a means to an end. Incineration is attained by setting the refuse ablaze. Fire is formed by combination of light heat and oxygen. At this point, we can say incineration is the destruction of combustible refuse using direct flame, plus oxygen and the re use reduced to one fifth of its original volume. Its operation may then be said to be either open or close incineration.

3. Controlled Tipping (Sanitary Landfill):- Sanitary land fill is an engineered method of disposing solid waste on land by spreading it in thin layers, compacting them to the smallest particle volume and covering it with soil each working day, in a manner that the environment is protected. Sanitary landfill is the most efficient system of refuse disposal because in this case, there is no residue and a useless piece of land becomes useful.

4. Recycling method: - They are simultaneously used to refer to the recovery of certain solid waste components for refuse. Other residues of pulverization, composting and incineration can be said to have been recycled or salvaged if the residues are used for one or other purpose. Components that are more amendable to recovery are those for which market exists and which are present in the waste in sufficient quantity to justify their separation. Materials that have been recovered from solid waste include paper, cardboard, plastic, glass, ferrous metals, aluminum and other residual nonferrous metal. Certain industries involve in utilizing waste are paper mill and cardboard factories, steel rolling mills, aluminum industries and plastic industries

\section{Impact of solid waste on climate change}

(Gupta M. S. 2016) Even before a cloth or the merchandise becomes solid waste, it goes through a protracted cycle that involves removing and process the raw materials, producing the merchandise, transporting the materials and merchandise to the market and exploitation energy to control the merchandise. Every of those activities has the potential to get gas emissions through one or a lot of the subsequent means:

- Energy consumption: Extracting and process raw materials, producing products, and transporting materials and merchandise to plug all inexperienced house gas emission by consumption of energy.

- Alkane Emissions: once organic wastes decompose in landfills it generates methane that is major element of inexperienced house gases.

- Carbon storage: Trees absorb carbon dioxide from air and store it in wood through carbon sequestration. Waste hindrance and use of wood and paper merchandise permit a lot of trees to stay standing within the forest wherever they'll still take away carbon dioxide from air that helps in minimizing the climate changes. Currently use reduces the alkane emission by preventing the consumption of energy for extracting and process the raw materials. Communities that square measure longing for ways in which to assist stop climate changes ought to get it on by implementing and integrated solid waste management program.

\section{Government policies on sanitation in nigeria}

(Stock R. 2010) The state's preoccupation with sanitation reached a peak in 1985 during the later months of Buhari regime. Environmental sanitation was chosen as the theme for the fifth phase of the War Against Indiscipline (WAI), which was launched in Kano on $29^{\text {th } J u l y, ~} 1985$ by the then chief of staff, supreme headquarters, Major-General Idiagbon. He announced that one million naira prize would be awarded for the cleanest capital. Frenzied sanitary activity ensured in all the state capitals, state sanitation task force where organized, additional sanitation workers were hired to remove rubbish, government offices and businesses were directed to close on designated clean up days, and the activities of mobile sanitation courts established to prosecute backsliders intensified. During the month of august 1985, many permanent piles of rubbish disappeared and drains which had been clogged for years were opened. Most of this work was accompanied by community self-help group, aided by the workers from offices and factories. This policy had brought some certain benefits then such as;

- Pathological environment which had constantly threaten the health of the urban poor were cleaned up. 
- The appearance of capital cities showed considerable improvement.

- Information on the importance of sanitation for health was disseminated.

- Environmental clean-up fostered the emergence of new community self-help groups.

- There was improvement in state and local government sanitation infrastructure.

National Policy on Environment, Plan, 1989 "The strategic objective of the National Policy on the Environment is to coordinate environmental protection and natural resources conservation for sustainable development. This goal will be achieved by the following:

i) Securing a quality of environment adequate for good health and wellbeing;

ii) promoting an understanding of the essential linkages between the environment, social and economic development issues;

iii) Encouraging individual and community participation in environmental improvement initiatives;

iv) Raising public awareness and engendering a national culture of environmental preservation; and

v) Building partnership among all stakeholders including government at all levels, international institutions and governments, non-governmental agencies and communities on environmental matters."

WaterAid (2007) Sanitation policy 2004 the current national environmental sanitation policy (NESP) was developed by the federal of environment and published, after approval by the president of the federal republic of Nigeria, and the national executive council, in January 2005. The policy covers: solid waste; medical waste management; excreta and sewage management; food sanitation; sanitary inspection of premises; market and abattoir management; adequate potable water supply; school sanitation; pest and vector control; management of urban drainage; controlled of reared and stray animals; disposal of the dead (humans and animal); weed and vegetation control and hygiene education and promotion. The objective of the 2004 sanitation policy is for all Nigerians to have access to adequate, affordable and sustainable sanitation through the active participation of federal, state and local governments, NGOs, development partners, private sector, communities, households and individuals.

\section{Objectives}

- To determine the public perception on solid waste management.

- To provide government with an insight about solid waste management and possible creation of strict policy by the government to its management.

\section{Significance}

With the significant increase in urbanization and population, solid waste accumulation is in the forfront, and the improper disposal of such waste materials will lead to an unsanitary conditions, leading to environmental pollution and outbreak of diseases, which is a negative to the economy of the state. Therefore the task of having a proper waste management is a most on all populations for better health and environment.

\section{Methodology}

\section{Study design}

A study, using cluster sampling technique, will be carried out to determine the perception of the public toward solid waste management and related government policies using content and face validation questionnaire on solid waste management among public. The study will be conducted among 400 subjects (sellers in Kasuwan Kurmi) of different age groups and educational levels in the month of July-august 2015 in Kasuwan Kurmi area of Kano metropolis, Kano state, Nigeria.

\section{Study population}

The study was performed in Kasuwan Kurmi area of Kano metropolis, Kano state, Nigeria. The respondents were 12years and above whom are Nigerians with no hearing or visual impairment and have the ability to comprehend the questionnaire. The respondent's characteristics that is included in the questionnaire are gender, age, religion and marital status. Participation in the study was voluntary and the questionnaire were administered by the interviewer. 


\section{Study sample size}

\section{Sample size estimation}

The sample size was determined using the formula

$$
\mathrm{n}=\mathrm{Z}^{2} \mathrm{pq} / \mathrm{d}^{2}
$$

Where

$\mathrm{n}=$ minimum sample size desired $\mathrm{Z}_{1-\alpha / 2}=$ standard normal deviation at $95 \%$ confidence levels $=1.96$

$\mathrm{P}=$ estimated proportion of variable of interest in the population (proportion of traders in Kurmi

Market $)=87.6 \% \mathrm{p}=0.876$

$\mathrm{q}=$ complementary probability of estimated proportion of variable of interest in the population

(proportion of traders in Kurmi Market) $=1-\mathrm{P}=1-0.876=0.124$

$\mathrm{d}=$ level of precision $=5 \%=0.05$ i.e. we would like the result to be within $5 \%$ of the true value

$\mathrm{N}=1.96^{2} \times(1-0.876) / 0.052=191$

To compensate for non-response and poorly completed questionnaires, the desired sample size,

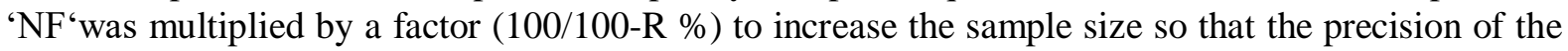
study shall not be jeopardized; $\mathrm{R} \%$ is the percentage loss to non-response by participants or poorly filled questionnaire by the interviewer; assumed to be $10 \%$.

To compensate for non-response of $10 \%$, we used (NF x 1/1-R \%),

Were $\mathrm{NF}=$ calculated sample size

$\mathrm{R} \%=$ Non-response rate

Therefore, $\mathrm{N}=191 \times 1 / 1-0.1=211.7 \approx 212$.

So 400 questionnaires where used.

\section{Sampling technique for study participants - systematic random sampling}

Sampling interval was generated using a formula $K=N / n$, where:

$\mathrm{K}=$ Sampling interval

$\mathrm{N}=$ Total number of traders in Kurmi Market $=\sim 1200$

It was used/adopted as the Sampling frame

$\mathrm{n}=$ Calculated sample size $=400$

Therefore, $\mathrm{K}=3$

A client is considered as a sampling unit

Numbers were allocated to each participant within the sampling frame (proportion of traders in Kurmi Market).

First participant was selected from the first three traders in the market using simple random sampling.

Then the rest of the participants were selected as every subsequent three traders till the desired sample size (400) was obtained.

\section{Survey instrument (Questionnaire)}

The questionnaire was prepared in English language which is relevant to the public perception on solid waste management. An informed consent was taken from the subject while conducting the survey for their participation in the study. Participants were given a questionnaire and were asked to administer on the socio-demographic characteristics, public perception on solid waste management and related government policy. Explanation were provided to those that didn't understand the questionnaire to assist them complete it. Those that fill in the questionnaire were further enlightened on solid waste management to improve, remind and share to others. Participants were also encouraged to participate in solid waste proper disposal and management for healthy environment.

\section{Statistical analysis}

The participants' demographic characteristics was illustrated using descriptive statistics. Categorical variables was shown as percentage while continues variable was depicted as mean +/- standard deviation. In addition, frequencies of variables was calculated. The statistical software (SPSS) was used to compile and analyze the data. 
DOI: 10.21522/TIJPH.2013.06.01.Art001

ISSN: $2520-3134$

\section{Results}

Table 1.1. Socio-demographic data

\begin{tabular}{llll}
\hline S/No & Variable & Responses & No (Percentage) \\
\hline 1 & Age(years) & $12-20$ & $57(15.1 \%)$ \\
& & $21-30$ & $154(40.7 \%)$ \\
& & $>41-40$ & $111(29.4 \%)$ \\
& & $56(14.8 \%)$ \\
\hline 2 & Sex & Male & $264(69.8 \%)$ \\
& & Female & $114(30.2 \%)$ \\
\hline 3 & Educational & None & $42(11.1 \%)$ \\
& status & Primary & $178(47.1 \%)$ \\
& & Secondary & $106(28.0 \%)$ \\
& & Higher & $52(13.8 \%)$ \\
\hline 4 & education & \\
& & Single & $61(16.1 \%)$ \\
& & Married & $234(61.9 \%)$ \\
& & Divorced & $72(19.1 \%)$ \\
& & Widowed & $11(2.9 \%)$ \\
\hline
\end{tabular}

Table 1.2. Public perception on solid waste management

\begin{tabular}{|c|c|c|c|}
\hline S/NO & Variables & Number & Percentage (\%) \\
\hline \multirow[t]{4}{*}{5} & $\begin{array}{l}\text { Who is responsible for solid waste } \\
\text { management? }\end{array}$ & & \\
\hline & Individual & 27 & 7.1 \\
\hline & Government & 335 & 88.6 \\
\hline & don’t know & 16 & 4.3 \\
\hline \multirow[t]{5}{*}{6} & $\begin{array}{l}\text { Poor solid waste management can } \\
\text { lead to }\end{array}$ & & \\
\hline & vector breeding site & 111 & 29.4 \\
\hline & disease epidemic & 252 & 66.7 \\
\hline & healthier environment & 4 & 1.1 \\
\hline & don't know & 11 & 2.8 \\
\hline \multirow[t]{5}{*}{7} & $\begin{array}{l}\text { Which of the following is the most } \\
\text { hazardous waste? }\end{array}$ & & \\
\hline & kitchen garbage & 67 & 17.7 \\
\hline & hospital waste & 183 & 48.4 \\
\hline & Industrial waste & 122 & 32.3 \\
\hline & don't know & 6 & 1.6 \\
\hline \multirow[t]{5}{*}{8} & $\begin{array}{l}\text { What is the best way for solid waste } \\
\text { management? }\end{array}$ & & \\
\hline & Land refill & 43 & 11.4 \\
\hline & Burning & 202 & 53.4 \\
\hline & Recycling & 41 & 10.8 \\
\hline & disposed of on the street & 92 & 24.4 \\
\hline \multirow[t]{4}{*}{9} & $\begin{array}{l}\text { Solid waste can be converted to } \\
\text { wealth }\end{array}$ & & \\
\hline & Agreed & 253 & 66.9 \\
\hline & Disagreed & 48 & 12.7 \\
\hline & Don't know & 77 & 20.4 \\
\hline
\end{tabular}


Table 1.3. Government policy

\begin{tabular}{|c|c|c|c|}
\hline S/No & Variable & Number & Percentage (\%) \\
\hline \multirow[t]{4}{*}{10} & $\begin{array}{l}\text { Have the government adopted an official day } \\
\text { for sanitation? }\end{array}$ & & \\
\hline & Yes & 354 & 93.7 \\
\hline & No & 5 & 6.3 \\
\hline & Don't know & 19 & 5.0 \\
\hline \multirow[t]{4}{*}{11} & $\begin{array}{l}\text { Is there a coordinating body to oversee the } \\
\text { sanitation policy in the metropolis? }\end{array}$ & & \\
\hline & Yes & 339 & 89.7 \\
\hline & No & 11 & 2.9 \\
\hline & Don’t know & 28 & 7.4 \\
\hline \multirow[t]{4}{*}{12} & $\begin{array}{l}\text { Is there need for extra training for those } \\
\text { responsible to oversee the program executed? }\end{array}$ & & \\
\hline & Yes & 212 & 56.1 \\
\hline & No & 106 & 28.0 \\
\hline & Don't know & 60 & 15.9 \\
\hline \multirow[t]{5}{*}{13} & $\begin{array}{l}\text { Do you have any of the following service in } \\
\text { your community? }\end{array}$ & & \\
\hline & Municipal composting plant & 45 & 11.9 \\
\hline & municipal recycling plant & 23 & 6.1 \\
\hline & hazard waste storage depot & 0 & 0 \\
\hline & don't know & 310 & 82.0 \\
\hline \multirow[t]{4}{*}{14} & $\begin{array}{l}\text { Should government make sanitation week } \\
\text { compulsory? }\end{array}$ & & \\
\hline & Yes & 77 & 20.4 \\
\hline & No & 259 & 68.5 \\
\hline & Don't know & 42 & 11.1 \\
\hline \multirow[t]{4}{*}{15} & $\begin{array}{l}\text { Should government stop participating in } \\
\text { Environmental sanitation? }\end{array}$ & & \\
\hline & Yes & 37 & 9.8 \\
\hline & No & 331 & 87.6 \\
\hline & Don't know & 10 & 2.6 \\
\hline
\end{tabular}

\section{Observation and discussion}

Total questionnaire distributed was 400 , out of which 378 were recovered while the remaining 22 was lost. From the recovered 378, observations made were as follows;

Table 1.1 showed the socio-demographic distribution of the population, out of which we have the following variables: Age distribution into four groups, majority of the respondents are between the age of 21-30 having $40.7 \%$, followed by $31-40$ having $29.4 \%, 12-20$ had $15.1 \%$ while the least of all comes from the age group above 41 years with $14.8 \%$. Sex distribution of respondents about $69.8 \%$ where males while $30.2 \%$ where females. The sex distribution could be for the fact that Kano is a Muslim dominated community where women are mostly not allowed to accept invitation without the approval from their husbands or parents. The next variable was educational status in which we have those that had no formal training at all constituting about only $11.1 \%$ which is the least of all, but those that stopped at primary school made up the highest percentage of the respondents, having about $47.1 \%$. Secondary school and higher level had $28.0 \%$ and $13.8 \%$ respectively. The last variable under table 1.1 is the marital status, the married ones made up the majority of the distribution with $61.9 \%$, the least comes from the widowed having only $2.9 \%$, the single and divorced had $16.1 \%$ and $19.1 \%$ respectively.

Table 1.2 had five variables that evaluates the public perception on solid waste management. The first variable was who is responsible for solid waste management? This is just to have the insight of who they thought is suppose manage the solid waste, majority of the respondents answered government, this is to show the believe in the people that they have no responsibility in what so ever for their environmental hygiene, they constitute up to $88.6 \%$, about $7.1 \%$ answered as the responsibility of the 
individual and $4.3 \%$ said they don't know. The second variable from this table was asking about what poor solid waste management can lead to, most of the respondents said it will lead to disease epidemic, $66.7 \%$, the least of them said it will lead to healthier environment, $1.1 \%$, the remaining said it leads to vector breeding sits or they don't know with percentages $29.4 \%$ and $2.8 \%$ respectively. The next variable was to know if they knew which is the most hazardous waste, the one that can cause threat or lethal to life, majority said it's the hospital waste, about $48.4 \%$, the least of them constituting about $1.6 \%$ said they don't know, then about $32.3 \%$ and $17.7 \%$ said from the industry and kitchen respectively. The next variable on the table was to assess the people's knowledge about best way of solid waste management, majority of them said burning is the best, $53.4 \%$. Least of them said recycling, $10.8 \%$, I think this is because of the level of literacy in the population, about $24.4 \%$ and $11.4 \%$ said disposed on the street and land refill respective. The next item on the table is assessing the economic perception of the population on solid waste management. its asking about solid waste can be converted to wealth, $66.9 \%$ which is the majority answered agreed, I think this is because the non-formally educated ones are still part of waste recycling in Kano. About $12.7 \%$ disagreed and $20.4 \%$ said they don't know.

Table 1.3 had six variables, it's about the related government policy. The first variable is whether the government had adopted an official day for sanitation, majority of the respondents said yes, about 93.7\%, I think its because there is restriction of movements and closure of places of business that made almost everyone aware of it, about $6.3 \%$ said no, maybe they are new settlers of didn't understand the question correctly, about 5\% said they don't know. The second variable was asking if the government had put any coordinating body to oversee the sanitation policy in the metropolis, about $89.7 \%$ said yes, some even went ahead describing the sanitation board for me during the interview, and that the tippers and trucks do move around town often, $2.9 \%$ said no and $7.4 \%$ responded they don't know. The third question was asking about if there is need to give extra training for those responsible to oversee the sanitation program. Quite sure those that said yes were the majority, making up to $56.1 \%$, but about $28.0 \%$ and $15.9 \%$ said no and don't know respectively. The fourth variable was asking if they have any of the following services in their community, $11.9 \%$ chose municipal composting plant, $6.1 \%$ chose municipal recycling plant, nobody said they have hazard waste storage depot, about $82.0 \%$ said they don't know. When asked if government should make sanitation week compulsory, majority constituting about $68.5 \%$ said no, about $20 \%$ said yes and $11.1 \%$ said they don't know. The last variable was asking about if government should stop participating in sanitation activities, about $87.6 \%$ said no, $9.8 \%$ said yes and $2.6 \%$ where not sure, they don't know.

\section{Summary and conclusion}

The above project work was carried out to evaluate the level of public perception on solid waste management and related government policy among traders in Kurmi Market of Kano metropolis of Kano state. From the demographic distribution we can see that the male to female ratio is approximately $2: 3$, which in relation to Nigerian demographics profile as of 2014 showed a ratio of 1.04:1, but we can say it's because this study was carried out within a minute population in relation to the whole of Nigerian population. The ratio of literacy level in Kano metropolis to illiterates is 8:1, but this could be due to the fact that the studies was done inside the metropolis, were access to education is a little easy compared to if it would have been done in the rural area, because Nigeria has the illiteracy ratio of $56.9 \%$ to literacy level of $43.1 \%$ in 2014 , out of which higher level is to the northern part of the country.

According to the results analyzed about public perception on solid waste management, it can be seen that about $88.6 \%$ agreed that it's the responsibility of the government to manage solid waste, but the populace are supposed to be enlightened about the fact that this is responsibility of both the government and the individuals, because this indirectly showed why waste management could be a problem among them, they will love to leave all the work to the government. Poor solid waste management can lead to vector breeding site and disease epidemics, both situations will worsen the health of the people. Most of the respondents took hospital waste as the most hazardous, about $48.4 \%$ of them, those $32.3 \%$ that chose industries probably are among the literate once. The best way of solid waste management is land refill, but majority of the respondents chose burning, about $53.4 \%$, from here we can see that there is a need to further educate them about global warming, proper waste recycling and land refilling methods. They are far better than burning. Waste to wealth is a major ways in which disposed wastes can be further processed into useable. But from the above results, most respondents know about it, this could 
be because mostly the lower classes with little or no education are involved in garbage selection and selling, so they know about such system, that further increases the number of awareness.

From the third table, which is about government policy, almost all the respondents agree on the fact that there is an official day for sanitation. This is because it's done in every last Saturday of the month, of which roads will be closed down, business places locked until after 10:00am, the official hour for the sanitation to be over. This is done to allow people stay at home and participate in the exercise. There is a coordinating body known as REMASB (Kano State Refuse Management and Sanitation Board) which are responsible for solid waste management in Kano metropolis. Majority keep with the fact that the members of REMASB need extra training to carry out their duties. Most of the populations are ignorant about composting plant, recycling plant and hazard waste storage deport. It seems the metropolis is more into burning and land refill in some areas. Kano metropolis is a central market area, most of the populations are business men and women, when asked about government making sanitation compulsory every week, and most of them said no. about $68.5 \%$. But this is based on self-interest as they don't want their business be altered. The help of government in participating in sanitation is so obvious that most of the respondents disagree for government to stop participating in sanitation. They know how much they suffer if government put a little delay before packing the refuse, that it even blocks the road.

In conclusion, we can see from this research that government need to give extra training for those responsible for coordinating the solid waste management in Kano state, provide different bins for different wastes at various locations within the metropolis. There is also the need to provide municipal composting plant, hazard waste storage depot and municipal recyclable plant. The population needs to know their responsibility in solid waste management through various enlightenment programs.

\section{References}

[1]. Aibor, M. S. and Olorunda, J. O. (2006): A Technical Handbook of Environmental Health in the 21st Century for Professional Students. Akure: His Mercy Publisher.

[2]. Danbuzu (2011) COMPOSITION AND SPATIAL DISTRIBUTION SOLID WASTE COLLECTIONS' POINTS IN URBAN KATSINA, NORTHERN NIGERIA. https://danbuzu.wordpress.com/2011/04/25/ananalysis-of-municipal-solid-waste-in-urban-katsina-northern-nigeria/ cited on 4/2/17 12:01pm

[3]. Gupta M.S. 2016. A Step Towards The Smart City- Solid Waste Management. International Journal Of Research In Business Management (Impact: Ijrbm) Issn (P): 2347-4572; Issn (E): 2321-886xvol. 4, Issue 10, Oct 2016, Pp 35-44

[4]. M Peil, Sanitation version small business: West Africa, 14 April 1986, pp 777-778 Nigeria Demographic Profile 2014: www.indexmundi.com/nigeria/demographics_profile.html. curbed on 31/08/15 17:10

[5]. Ogunbiyi is of the features unit, minister of information and strategy, Alausa, Ikeja. Business day: Published Wednesday September $17^{\text {th }} 2014$.

[6]. Ojeda-Benitez, S and Beraud-Lozano, J. L. (2003) the municipal solid waste cycle in Mexico. Final disposal, Resources, Conservation and Recycling, 39, 239-250. http://dx.doi.org/10.1016/50921-3449(03)00030-2. Retrieved on 21/07/2015 12:30pm.

[7]. Olanrewaju, O. O., Ilemobude, A. A., 2009. Waste to wealth: a case study of the Ondo state integrated waste recycling and treatment project, Nigeria. European journal of social sciences 8(1), 7-16.

[8]. P. O. U. Adogu, K. A. Uwakwe, N. B. Egenti, A. P. Okwuoha, I. B. Nkwocha 2015. Assessment of Waste Management Practices among Residents of Owerri Municipal Imo State. Journal of Environmental Protection, 2015, 6, 446-456 Published Online May 2015 in SciRes. http://www.scirp.org/journal/jep http://dx.doi.org/10.4236/jep.2015.65043

[9]. Post Offices-with map of LGA. NIPOST. Retrieved 2009-10-20. http://en.m.wikipedia.org/wiki/Kano_Municipal. Retrieved on 24/07/2015 11:15am.

[10]. Sewage and solid waste project unit 2000. The solid waste management program. Sewage and solid waste project unit, Barbados. http://www.solid.gov.bb/Resource/Brochures/programme/program02.asp. Retrieved on 21/07/2015 1:01pm.

[11]. Stock R. (2010) Environmental sanitation in Nigeria: Colonial and Contemporary. Robert Stock. (19742010) ROAPE/. http://www.roape.org. pp 19-31Retrieved on 21/07/2015 10:45am.

[12]. WaterAid 2007. Sanitation and Economic Development: Making a case for the MDG Orphan, http://www.wateraid.org/documents/sanitation_and_economic_development.pdf. 